\title{
Out of the frying-pan into the PWR
}

Amory B. Lovins, a consultant physicist, and British Representative of Friends of the Earth Inc., the US sistergroup of the independent UK group FOE Ltd., argues that US pressurised water reactors are an economic disaster

THE juggernaut advance of light-water reactors (LWRs), and especially pressurised-water reactors (PWRs), through world nuclear markets has seemed to their promoters a sort of manifest destiny. When Britain rejected PWRs for the second time, in 1974, the president of Westinghouse, which first developed them, replied magisterially that this was only "an interim solution, as we are not convinced that it addresses Britain's long-range energy needs." Since then, British electricity use has risen by less than $2 \%$, while excess output capacity above a reasonable $20 \%$ reserve margin has risen to $20 \%$ of peak output and may soon be 30 to $45 \%$. Closer analysis of energy use has also revealed not only that far more efficient use and even proven renewable sources are practicable and advantageous, but also that Britain already has twice as much electricity as is needed for the premium uses that can give value for money from this very costly, high-quality form of energy. Yet Westinghouse and its allies-including European vendors, the National Nuclear Corporation (NNC), and the Central Electricity Generating Board (CEGB) - are now back again. They argue that the British preference for advanced gascooled reactors - the last major indigenous programme of thermal reactors outside Canada-is a sentimental anomaly that now, bereft of further excuses, must give way to technical and economic rationality.

In an open letter to the Prime Minister of the United Kingdom, James Callaghan, on 21 December, Frinds of the Earth document a counter-argument. They suggest that the worldwide dominance of PWRs has arisen not from merit but from aggressive salesmanship and "a process of "mutual intoxication' whereby US promotional institutions persuaded each other, then there counterparts abroad, that LWRs' supposed merits were real and had been demonstrated when in fact they had not and still have not been realised: the distinction between promotional prospectus and critical evaluation was completely obscured". Thus, according to a forthcoming study*, the gas-graphite system displaced in France by PWRs was in retrospcct supcrior, but policymakers were caught up in a skilfully propagated and wholly unfounded PWR euphoria. Systematically mistaking hope for fact, they thought they knew how much PWRs would cost to build and to run, how reliable they would be, and what fuel burnup they would attain. US experience has fallen far short of these expectations. Real capital costs have averaged more than twice as high as promised; real fuel-cycle costs will be about six times as high. Capacity factor has averaged 20 to $30 \%$ lower and burnup 20 to $40 \%$ lower than forecast. The picture is not getting brighter. Two recent studies, for example, show PWR capital costs rising by $20 \% \mathrm{y}^{-1}$ or $\$ 188 \mathrm{~kW}(\mathrm{e})^{-1} \mathrm{y}^{-1}$ in constant 1976 dollars-about three times as fast as coal-fired stations. Much European and Japanese experience is similarly disappointing. Yet NNC's latest report on reactor choice is not an analysis of independently established facts so much as a seller's advertisement of alleged virtues. It is remarkably like the promotional paper that USAEC staffers drafted for the European Community's "Three Wise Men" when they recommended twenty years ago that Europe switch to I.WRs.

*Light Water: How the Nuclear Dream Dissolved (New York: Basic Books, March 1978), by Professor 1. C. Bupp (Harvard Business School) and Dr J.-C. Derian (an official of the French regional development ministry DATAR).
In the US, the euphoria has worn off abruptly. The doubtful economics of real (as opposed to paper) PWRs, uncertainties about demand, reliability, and safety, and the macroeconomic problems of a capital intensity 10 to 30 times that of new North Sea oil capacity have together led to what FOE call "the most dramatic collapse of a major industrial enterprise in history". US yearly domestic orders in 1972-6 (net of cancellations ascribed to the year of original ordering) were respectively $28,38,17,5$, and 3 reactors. In 1975-6, seven reactors were ordered, eight cancelled, and 13 deferred (six indefinitely). In 1977, two were ordered, four cancelled, and 26 deferred. This quickening disintegration has led Dr Schlesinger's' deputy to state that "the nuclear option has essentially disappeared" in the US.

Official forecasts of US nuclear capacity in the year 2000 have been falling so quickly that, extrapolating linearly, the 1978 forecast for 2000 should be zero (in fact the asymptote might be as high as $2 \frac{1}{2} \%$ of present US delivered energy use, or about the level of firewood). Nuclear expectations are likewise plunging in France, Germany, the UK, Japan, and elsewhere at such a rate that the 1979 forecast of 1985 OECD nuclear capacity should be zero. In Canada, which has had none of the US regulatory problems, forecasts have dived just as steeply as in the US, suggesting that the cause is not some political artifact but fundamental market forces -which President Carter's energy policy does nothing to discourage and much to reinforce. In short, PWRs are proving all but unsaleable throughout the industrial world. Staunching the rapid haemorrhage of money and staff from reactor vendors is requiring proliferative exports to developing countries, lavishly subsidised by exporting governments. This is not much of a vote of confidence in PWRs or in Britain prospects for profitably exporting them. Indeed, reports in the financial press suggest that no LWR vendor has sold reactors at a profit: vendors' cumulative losses are said to exceed $£ 1000$ million in the US (over half of it for Westinghouse alone), $£ 250$ million in Japan, over $£ 200$ million in West Germany, and large but undisclosed sums in France and elsewhere. This hardly seems a promising line for Britain to follow-salvaging and refloating other countries' lame ducks.

Further, while PWR advocates consider the vexed question of pressure-vessel rupture adequately resolved, FOE (like most US observers) have long put this issue rather far down a very long list of serious safety problems. Their letter documents ten compendia showing over 200 unresolved major safety problems of PWRs, most of them officially acknowledged. British advocates' optimism about PWR safety may rest not on the detailed knowledge which they claim, but on the lack of it which they have in the past displayed (notably in the 1973-4 controversy) and which the uncharitable can infer from the $1977 \mathrm{NNC}$ report. It is possible that the NNC, CEGB, DOE, and Nuclear Inspectorate staff have in fact all done their homework. There is, however, no published reason to believe this is the case. They may still not have consulted the main original sources, preferring to rely, as in 1973-4, on summaries prepared by US parties that could hardly he considered disinterested. FOE have therefore proposed that specified papers well known in the US debate be the subject of public colloquy in Britain between highly qualified US critics and their British adversaries.

Only four years ago, the NNC and CEGB were pressing for an urgent programme of 32 PWRs-which, if adopted, might well by now have pushed the British electronuclear industry over the brink of ruin. The advocates of haste at that time were wrong; the advocates of caution were right. So it may be again. 